\title{
Indirect Spectrophotometric Determination of Amoxicillin by Oxidative with Cerium ammonium Nitrate Using Arsenazo III as a Reagent
}

\author{
AMEERA H. HAMED ${ }^{1}$, SURA K. IBRAHIM ${ }^{1}$, \\ SAADIYAHA.DHAHIR $^{1 *}$ and AMAL H. MHEMEED ${ }^{2}$ \\ ${ }^{1}$ Department of Chemistry, University of Baghdad, College Science for Women, Iraq. \\ ${ }^{2}$ College of Pharmacy' University of Masan, Iraq \\ sadiataher@gmail.com
}

Received 11 September 2018 / Accepted 3 October 2018

\begin{abstract}
A simple, accurate and sensitive spectrophotometric way used for preparation. The suggested method depends on using arsenazo III as reagent. The current method was depending on oxidative coupling reaction of amoxicillin by cerium ammonium nitrate with arsenazo III in the presence of sulfuric acid as acidic media. Then reaction Ce(III) with arsenazo III to form pink water-soluble dye product that has a maximum absorption at max $500 \mathrm{~nm}$. Beers law is obeyed in the concentration of $\left(1-10 \mu \mathrm{gmL}^{-1}\right)$. The molar absorptivity is $3 \times 10^{4} \mathrm{~L}_{\mathrm{mol}}{ }^{-1} \cdot \mathrm{cm}^{-1}$, a sandal sensitivity of $0.012 \mu \mathrm{gcm}^{-2}$. Limit of detection (LOD) and limit of quantitation are $0.00874 \mu \mathrm{gmL}^{-1}$, (LOQ) $0.0291 \mu \mathrm{gmL}^{-1}$ respectively. The analytical recovery of the new method was good (100.72\%). The method successfully applied for the determination of Amoxicillin in pharmaceutical preparations.
\end{abstract}

Keywords: Amoxicillin, Spectrophotometry, Arsenazo III

\section{Introduction}

Amoxicillin (Scheme 1) is an antibiotic active against a wide large of gram-positive and a limited range of gram-negative organisms. Amoxicillin work by control the synthesis of bacterial cell walls. It controls cross-linkage between the linear peptidoglycan polymer chains that industrialize a prime component of the cell wall of gram-positive bacteria. It is ordinarily the medicine of choice within the group because it is better absorbed, following oral direction, than other beta-lactam antibiotics. Amoxicillin is oversensitive to degeneracy by 3-lactamaseproducing bacteria, and so may be given with clavulanic acid to decrease its oversensitive in prior. In past studies; the estimation of amoxicillin in medicinal preparations containing only amoxicillin was made by using several methods including spectrophotometry ${ }^{1-7}$, HPLC $^{8-10}$, spectrofluorimetry ${ }^{11}$, flow-injection analysis ${ }^{12-17}$, voltammetry and polarography ${ }^{18,19}$ and titrimetry ${ }^{20}$. Estimation of amoxicillin in the existence of sulbactam sodium clavulanic acid, 
fluxacilline and metronidazole was realized by using $\mathrm{HPLC}^{21-26,} \mathrm{TLC}^{27}, \mathrm{CE}^{28}$ and chemometry $^{29}$. In the present research, selective spectrophotometric estimation of amoxicillin based on the oxidative drug by $\mathrm{Ce}(\mathrm{IV})$ and coupling the product $\mathrm{Ce}(\mathrm{III})$ with arsenazo III (Scheme 2), which results to formation coloured products in acidic medium.<smiles>CC1(C)S[C@H]2C(C(=O)O)N3C(=O)[C@H](NC(=O)c4cccc(O)c4)[C@H]3C21</smiles>

Scheme 1. The chemical structure of amoxicillin<smiles>O=S(=O)(O)c1cccc(N=Nc2c(S(=O)(=O)O)cc3c(c2O)=C(O)C(S(=O)(=O)O)C(S(=O)(=O)O)C=3)c1</smiles>

Scheme 2. The chemical structure of arsenazo III

\section{Experimental}

UV Visible spectrophotometer (1800 Shimadzu), Spectrophotometric UV-1100 with $1 \mathrm{~cm}$ matched quartz cells was used for absorption measurements, WTW 720 PH meter Germany, Electronic balance Sartorius AG Germany was used.

\section{Reagents}

1. Stock solution from drug $\left(1000 \mu \mathrm{gmL}^{-1}\right)$ of amoxicillin (SDI Samara - Iraq) were prepared by dissolving $(0.1 \mathrm{~g})$ of amoxicillin in $20 \mathrm{~mL}$ absolute methanol and then diluted with distilled water to $100 \mathrm{~mL}$.

2. Stock solution of cerium ammonium nitrate was prepared by dissolving $(0.1 \mathrm{~g})$ in distilled water and diluting to mark in $100 \mathrm{~mL}$ volumetric flask.

3. Stock solution of arsenazo III was prepared by dissolving $(0.1 \mathrm{~g})$ in distilled water and diluting to mark in $100 \mathrm{~mL}$ volumetric flask.

4. Sulfuric acid $\left(\mathrm{H}_{2} \mathrm{SO}_{4} 0.5 \mathrm{M}\right)$ was prepared by taking $2.72 \mathrm{~mL}$ from concentrated sulfuric acid and diluted with distilled water to mark in $100 \mathrm{~mL}$ volumetric flask.

\section{Procedure for assay of amoxicillin in pharmaceutical preparations (capsules)} Amoxicillin capsule

The proposed method was applied successfully to the determination of amoxicillin (AMXT) in different pharmaceutical formulations, which is commercially available in market (The state company for drug industrial and medical application Global pharma, UAE) and used for the analysis. Each capsule contains $500 \mathrm{mg}$ amoxicillin. 10 Capsules were powdered then was dissolved in $20 \mathrm{~mL}$ methanol and made up to $100 \mathrm{~mL}$ using distilled water. This solution was diluted quantitatively to form a concentration in the range of calibration curve.

\section{Recommended procedures}

Working standard solutions were prepared by serial dilution of $100 \mu \mathrm{gmL}^{-1}$ amoxicillin to the final volume of $25 \mathrm{~mL}$ volumetric flask to cover the range of calibration curve (1-10 $\left.\mu \mathrm{gmL}^{-1}\right)$, then $(3 \mathrm{~mL})$ cerium ammonium nitrate $\left(100 \mu \mathrm{gmL}^{-1}\right)$ was added and shaken well. 
Then $3 \mathrm{~mL}$ of arsenazo III $\left(100 \mu \mathrm{gmL}^{-1}\right)$ and $0.3 \mathrm{~mL}$ of $\mathrm{H}_{2} \mathrm{SO}_{4}(0.5 \mathrm{M})$ were added to the mixture then diluted to the mark using distilled water and allowed to stand the flasks for $30 \mathrm{~min}$ at room temperature at $25^{\circ} \dot{\mathrm{C}}$. The absorption was monitored at $500 \mathrm{~nm}$ against the blank.

\section{Results and Discussion}

Amoxicillin drug react with cerium ammonium nitrate and arsenazo III in the presence of sulfuric acid as acidic media to form an intense pink colour product that can be measured spectrophotometrically at $500 \mathrm{~nm}$ Figure 1.

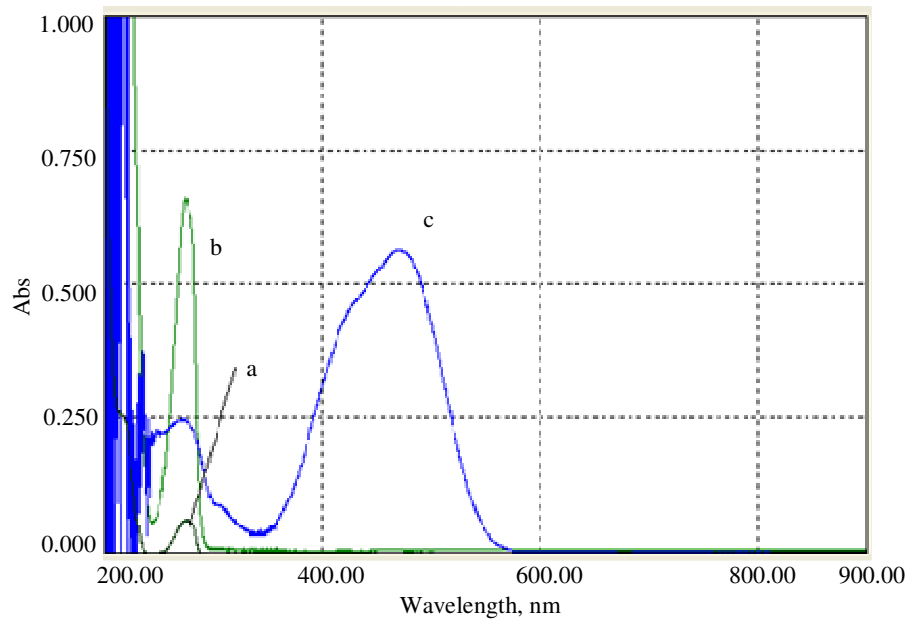

Figure 1. (a) Amoxicillin vs. distilled water, (b) Arsenazo III vs. distilled water, (c) Complex product $v s$. blank

\section{Optimization of the reaction conditions}

The main consideration with the optimization to study the effect of deferent parameters on the absorption intensity of the colour complex formed. All optimization for the reaction conditions were studied. The factors affecting color development, reproducibility, sensitivity and conformity with Beers law were investigated with amoxicillin.

\section{Effect of cerium ammonium nitrate volume}

The optimum concentration of cerium ammonium nitrate solution was found to be $3 \mathrm{~mL}$ of cerium nitrate ammonium $\left(100 \mu \mathrm{gmL}^{-1}\right)$ for amoxicillin (Figure 2).

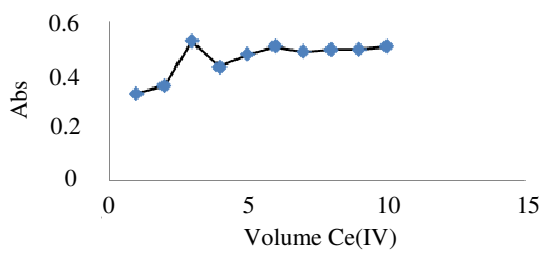

Figure 2. Effect of cerium ammonium nitrate volume

\section{Effect of arsenazo III volume}

The amount of coupling agent was optimized by adding 1-10 $\mathrm{mL}$ of $\left(100 \mu \mathrm{gmL}^{-1}\right)$ arsenazo III. It was found that maximum and stable colors were formed with $3 \mathrm{~mL}$ of arsenazo III solution for amoxicillin in final volume of $25 \mathrm{~mL}$ (Figure 3). 


\section{Effect of different temperature}

Optimization at different temperatures on oxidative coupling of amoxicillin led to obtain a high absorption (Figure 4$)$ at room temperature $\left(25^{\circ} \mathrm{C}\right)$.

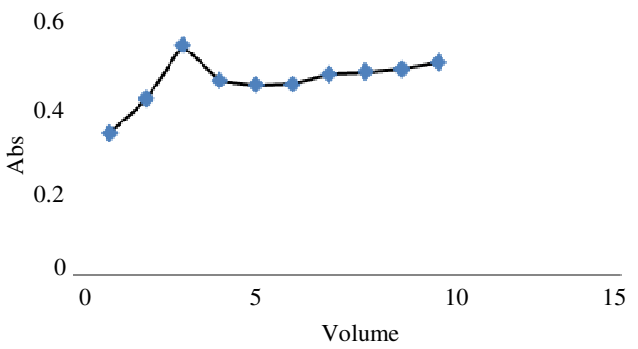

Figure 3. Effect of arsenazo III volume

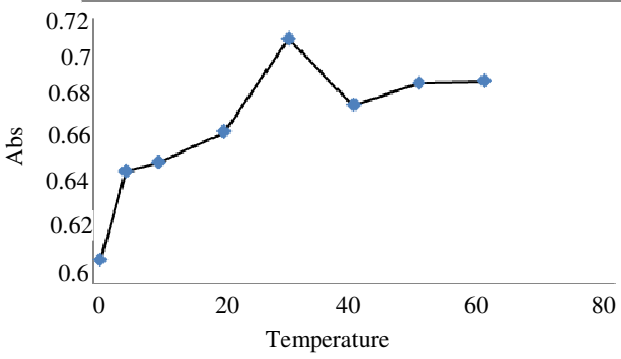

Figure 4. Effect of different temperature

\section{Effect of sulfuric acid volume}

The maximum absorption was observed at $0.3 \mathrm{~mL}$ of sulfuric acid $(0.5 \mathrm{M})$ for amoxicillin, so $0.3 \mathrm{~mL}$ of sulfuric acid was selected.

\section{Effect of order of addition}

The absorption of pink product dye was monitored via changing the order of addition, which led to the following order: (Drug: cerium ammonium nitrate: ArsenazoIII: sulfuric acid). Due to show the highest absorption and it was selected for further use (Table 1).

Table 1. Effect of order of addition

\begin{tabular}{clcc}
\hline No. & & \multicolumn{1}{c}{ Order of addition } & $\begin{array}{c}\text { Absorbance } \\
\text { at 500 nm }\end{array}$ \\
\hline 1 & Drug: & Cerium ammonium nitrate :Arsenazo III : sulfuric acid & 0.392 \\
2 & Drug: & Sulfuric acid: cerium ammonium nitrate : arsenazo III & 0.362 \\
3 & Drug: & Arsenazo III: cerium ammonium nitrate : sulfuric acid & 0.371 \\
4 & Drug: & Cerium ammonium nitrate : sulfuric acid: arsenazo II & 0.388 \\
5 & Sulfuric acid: Drug: cerium ammonium nitrate $:$ arsenazo III & 0.381 \\
\hline
\end{tabular}

\section{Calibration Curve}

Table 2 summarizes the optical characteristics and the analytical figures of merit of determination of amoxicillin based on optimization condition. The excellent correlation coefficient 0.9997 confirms linear correlation between absorption signal and amoxicillin concentration. The concentration range is $1-10 \mu \mathrm{gmL}^{-1}$ and the linear regression equation is $\mathrm{Y}=0.0803 \mathrm{x}+0.0208$ (Figure 5).

Table 2. Optical characteristics and statistical data for the determination of amoxicillin

\begin{tabular}{ll}
\hline Parameter & Value \\
\hline$\lambda_{\max }, \mathrm{nm}$ & 500 \\
Color & Pink \\
Linearity range, $\mu \mathrm{gmL}^{-1}$ & $1-10$ \\
Regression equation & $\mathrm{Y}=0.0803 \mathrm{x}+0.0208$ \\
Calibration sensitivity, $\mathrm{mL} \mu \mathrm{g}^{-1}$ & 0.0803 \\
Correlation of linearity & 0.9997 \\
Molar absorptivity, $\mathrm{L}_{\mathrm{mol}}{ }^{-1} \cdot \mathrm{cm}^{-1}$ & $3^{*} 10^{4}$ \\
Sandals sensitivity, $\mu \mathrm{gcm}^{-2}$ & 0.012 \\
\hline
\end{tabular}




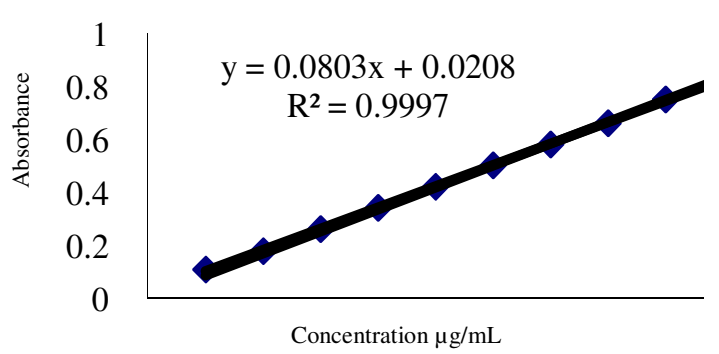

Figure 5. Calibration curve for the determination of amoxicillin

Nature of the dye product

Table 2 summarizes the optical characteristics and the analytical figures of merit of determination of amoxicillin based on optimization condition. The excellent correlation coefficient 0.9997 confirms linear correlation between absorption signal and amoxicillin concentration. The concentration range is $1-10 \mu \mathrm{gmL}^{-1}$ and the linear regression equation is $\mathrm{Y}=0.0803 \mathrm{x}+0.0208$.

\section{Analysis of amoxicillin in pharmaceutical preparations}

The feasibility of monitoring amoxicillin in pharmaceutical preparations via proposed method was successfully applied with the relative standard deviation demonstrate excellent accuracy and precision. Table 3 confirms the new suggested method procedure was compared with standard procedure.

Table 3. Analysis of amoxicillin in pharmaceutical preparations

\begin{tabular}{ccccccc}
\hline $\begin{array}{c}\text { Amount of } \\
\text { amoxicillin, } \mu \mathrm{g} / \mathrm{mL}\end{array}$ & *Found & $\begin{array}{c}\text { Recovery } \\
\%\end{array}$ & $\begin{array}{c}\text { Average } \\
\text { Recovery }\end{array}$ & $\begin{array}{c}\text { Error } \\
\%\end{array}$ & $\begin{array}{c}\text { Average } \\
\text { Error \% }\end{array}$ & RSD\% \\
\hline 8 & 8.6 & 107.5 & & 7.5 & & 0.956 \\
9 & 8.7 & 96.66 & \multirow{2}{*}{100.72} & 3.3 & 4.2 & 0.858 \\
10 & 9.8 & 98 & 2 & & 1.26 \\
\hline
\end{tabular}

\section{Conclusion}

*Average of five determinations

A simple, accurate and excellent spectrophotometric method was investigated for the determination of amoxicillin in pure and in pharmaceutical preparations. The proposed method can be carried out with no need for further steps such as solvent extraction step $\mathrm{pH}$ or temperature control.

\section{References}

1. Mouayed Q, Al-Abachi H H and Anas M A, Chim Acta, 2005, 554(1-2), 184-189; DOI:10.1016/j.aca.2005.08.030

2. Mohamed G G, J Pharm Biomed Anal, 2001, 24(4), 561-567; DOI:10.1016/S07317085(00)00463-5

3. Belal F, El-Kerdawy M M, El-Ashry S M and El-Wasseef D R, Farmaco, 2000, 55(11-12), 680-686; DOI:10.1016/S0014-827X(00)00080-X

4. Fernandez-Gonzalez A, Badia R and Diaz-Garcia M E, J Pharm Biomed Anal, 2002, 29(4), 669-679; DOI:10.1016/S0731-7085(02)00185-1

5. Salem H and Saleh G A, J Pharm Biomed Anal, 2002, 28(6), 1205-1213; DOI:10.15406/japlr.2016.02.00015 
6. Nagaralli B S, Seetharamappa J and Melwanki M B, J Pharm Biomed Anal, 2002, 29(5), 859-864; DOI:10.1016/S0731-7085(02)00210-8

7. Morgil F I and Kestek A, Gazi Univ Eczaci Fat Derg., 1990, 7(1), 33-42.

8. Samanidou V F, Evaggelopoulou E N and Papadoyannis I N, J Sep Sci., 2006, 29(11), 1550-1560; DOI:10.1002/jssc.200600081

9. Hong C C, Lin C L, Tsai C E and Kondo F, Am J Vet Res., 1995, 56(3), 297-303;

10. Lebelle M J, Wilson W L and Lauriault G, J Chromatogr., 1980, 202(1), 144-147; DOI:10.1016/S0021-9673(00)80090-4

11. El Walily A F, Gazy A A, Belal S F and Khamis E F, J Pharm Biomed Anal, 1999, 20(4), 643-653; DOI:10.1016/S0731-7085(99)00017-5

12. Cao W, Yang J H, Sun C X, Chen Y J and Gao Q F, Luminescence, 2005, 20(1), 20-24; DOI:10.1002/bio.796

13. $\mathrm{Li} \mathrm{Y}$, Tang $\mathrm{Y}$, Yao $\mathrm{H}$ and $\mathrm{Fu}$ J, Luminescence, 2003, 18(6), 313-317; DOI:10.1002/bio.741

14. Li Y and Lu J, Luminescence, 2006, 21(4), 251-255; DOI:10.1002/bio.915

15. Fernandez-Gonzalez A, Badia R and Diaz-Garcia M E, J Pharm Biomed Anal, 2002, 29(4), 669-679; DOI:10.1016/S0731-7085(02)00185-1

16. Sun Y, Tang Y, Yao $\mathrm{H}$ and Li Y, Anal Sci., 2005, 21(4), 457-460; DOI:10.2116/analsci.21.457

17. Garcia M S, Sanchez-Pedreno C, Albero M I and Rodenas V, J Pharm Biomed Anal, 1994, 12(12), 1585-1589; DOI:10.1016/0731-7085(94)00108-1

18. Kapetanovic V and Veselinovic D, Archiv der Pharmazie, 1988, 321(9), 559-560; DOI:10.1002/ardp.19883210914

19. Uslu B and Biryol L, J Pharm Biomed Anal, 1999, 20(3), 591-598;

DOI:10.1016/S0731-7085(99)00059-X

20. Kihc E, Koseoglu F and Akay M A, J Pharm Biomed Anal., 1994, 12(3), 347-352; DOI:10.1016/0731-7085(94)90010-8

21. Liu H, Wang H and Sunderland V B, J Pharm Biomed Anal, 2005, 37(2), 395-398; DOI:10.1016/j.jpba.2004.10.029

22. Wang P, Qi M, Sun Y and Yang J, J Pharm Biomed Anal, 2004, 36(3), 565-569; DOI:10.1016/j.jpba.2004.07.015

23. Aghazadeh A and Kazemifard G, J Pharm Biomed Anal, 2001, 25(2), 325-329; DOI:10.1016/S0731-7085(00)00507-0

24. Abounassif M A, Abdel-Moety E M, Mohamed M E and Gad-Kariem R A, J Pharm Biomed Anal, 1991, 9(9), 731-735; DOI:10.1016/0731-7085(91)80214-T

25. Menelaou A, Somogyi A A, Barclay M L and Bochner F, J Chromatogr B Biomed Sci Appl., 1999, 731(2), 261-266; DOI:10.1016/S0378-4347(99)00241-8

26. Tsou T L, Wu J R, Young C D and Wang T M, J Pharm Biomed Anal, 1997, 15(8), 1197-1205; DOI:10.1016/S0731-7085(96)01960-7

27. Indrayanto G, Sa T K, Widjaja S, J AOAC Int., 2000, 83(6), 1493-1496.

28. Pajchel G, Pawlowski K and Tyski S, J Pharm Biomed Anal, 2002, 29(1-2), 75-81; DOI:10.1016/S0731-7085(02)00029-8

29 Pasamontes A and Callao M P, Anal Sci., 2006, 22(1), 131-135; DOI:10.2116/analsci.22.131 